\title{
Innovative technological restoration of gully susceptible riparian land and water sustainable productivity
}

\author{
R. C. Yadav ${ }^{1}$ \\ ${ }^{1}$ ICAR-CSWCRT, Research Centre, Asra
}

June 22, 2020

\begin{abstract}
Gully in the riparian areas remain at lowest elevation right from gully head cut, a gully link to join any link of higher order and then join any major river comprise of all features of riparian areas. The gullies suffer setback of sewage disposal and finally discharge it into rivers. Objective of this study was to develop an innovative measure so that sewage water is diverted along the down slope and a wetland created instead of allowing the waste water to join the gully network. The innovative measures are treatment of waste water in wetlands, storage facility for fresh water and rearing fish. The fishery in wetland will attract wild birds viz heron that thrives on aquatic primary food chain such as insects, leaches and fingerlings etc and their dropping rich in organic nitrogen $(\mathrm{N})$ and phosphorus $(\mathrm{P})$, called as Guano can be harvested. Case study of the treating gully as a sewage disposal channel, spoiling all good features of riparian areas is made to show this innovative development to solve several emerging problems following development of gullies in fulfillment of areas for growing population. Therefore, misdeeds which follow development and spoil entire scenario can be overcome and the riparian areas save from getting worsened. Additionally, innovative measures and their sequential steps create resource for prosperity and employment.
\end{abstract}

\section{Introduction}

Gully erosion is severe most stage of soil erosion initiated by splash erosion, followed by wash off erosion, rill formation cross grading and developing recently formed channel which receives and conveys intermittent runoff. Although this is a universal problem, but in alluvial soil region the network of gullies develops all along the river courses and due to high vertical falls both lateral and spatial extensive net work of gullies develop and such net works along rivers in India are called as ravines and internationally, the river system as riparian areas susceptible to gully erosion. The severity of gully erosion became severe from 1950 decades as revealed by long term data (Warren and Beaver, 1965) plot developed (Yadav 2019). The severity of soil erosion coincided with occurrence of intense rainfall and high vertical falls led to development of large areas becoming out of agriculture use in particular and loss of properties in general.Fig $\mathbf{1}$ depicts various scenarios of riparian areas susceptible to gully erosion. The gullied lands were reclaimed by special external funding from different donor agencies and vast areas were brought in to arable, specially terraced land that converted eroded land escapes a green productive land under irrigated as well as raned agriculture.

Fig1

After the development of work on reclamation of gullied land (Yadav et al.1989) Government of India conducted studies on productivity enhancement by such reclaimed gully watershed, which reveled success of such projects along Yamuna in Uttar Pradesh, Chambal river in Rajasthan and Madhya Pradesh along the River Chambal, a tributary to the rivers Yamuna and Maui in Gujarat (Bhushan et al., 1991, Bhutan et. al .1992, , 1997) .). An elucidating bulletin on gully and ravines erosion was release by the Government of India, which was prepared under consultancy work of the Government of India, Ministry of Agriculture and Cooperation by the research scientists of Research Centers for Gully erosion located at Agra, Kota 
and Vassar under the umbrella of the then Central Soil and Water Conservation Research and Training Institutes under apex research organization called as Indian Council of Agricultural Research, New Delhi. Yadav and Bhutan (2002) documented detailed accomplishment of research and developments on gully and ravines in the riparian areas, in India. The development enhanced exemplary enhancement and sustainable yield fulfilling local and country's food production reserve.

With development of prosperity and civilization created urbanization and development of urban facilities in rural areas, which had been vision of development in India by the past President of India late Dr A.P.J Abdul Kalama. In such developments all sewages were drained in to the existing river systems throughout India. The gullies remain at the lowest level and developing habitations treat the lowest point as last detonation for leaving sewage discharge, which worsen quality of river water. To clean the bad quality of water as a result of dumping all kind of domestic and industrial waste material and water spoiled quality of water. Many river action plans for cleaning of such bad quality waters were launched as prestigious river action plans called as famous Gang action plan, Yamuna Action plan and so on all regional rivers. In all endeavors the main treatment measures had been construction of sewage treatment plants (STPs), which in spite of long time persistent and rejoiced by the changing Governance did not produce any visible sign of improvement. All the efforts went waste, which became clear by self cleansing of not only one, but all river systems during lockdown period from March- May 2020, in India and similar situations that might have developed elsewhere. This fact led to conclusion that the river system should not receive such waste, disposal, be domestic or industrial, if water resources in the river system has to be maintained to keep water qualities free of pollutions, the gullies also being easy access to discharging from such sources suffered this setback. But, for this no attention could come from the Government side. The sewage water irrigation and poor gully condition spoiled entire scenarios of riparian areas, which had been developed after long research and developments, fund resources and human efforts.

Objective of the present study was to find innovative solution to such problems of riparian river systems in general and that susceptible to gully erosion in particular. The study developed innovative technology to eliminate the developing limitations. Case study includes National Research Setup along the river Yamuna, having densest network of gully and ravines of the world, along the river Yamuna at Etowah, in India, Manuscript contains such case study, innovative measures, their potential application and impact in solving problems of varying nature, called as, environmental food, prosperity and employment generation.

\section{Materials and Methods}

\subsection{Review of status of gullied lands in India}

Severely eroded lands were left barren and under grassland and vegetation, as it were considered lowest capability land out of arable land category. It was considered as lost land although it was under private ownership. In 1970 decades some land improvement measures were launched in states (Yadav et. al, 1989). As population grew centrally sponsored schemes on ravine reclamation were launched in four states called as Uttar Pradesh, Madhya Pradesh, Rajasthan and Gujarat states, where gully and ravines were severe problems along three river systems and spreading in the four states to enhance arable land and agricultural production (Yadav, et al., 1991). In early years of 1980s Operational Watershed Management Projects (ORP) were launched throughout the country and ravine reclaimed lands in watershed projects showed highly effective. In these projects lands were improved and local sources in form of pond, amicuts and even shallow wells supported irrigated agriculture in the developed land (Anonymous, 2003, Yadav and Bhushan, 2002). As food prosperity grew other developments of water supply and sanitations were also launched, where the sewage were released in the lowest point in the vicinity and in most cases in rivers in the cities and in pastoral region in the gully courses. Where such system of continuing natural drainage did not exist, it formed wetlands, which locked large land areas and quality limited waste waters. This situation led to spoilage of quality of fresh waters in rivers, and wetland with different environmental problems. Researches done elsewhere were used to water filtration by the water works and supply departments, but sewage disposal remained with lesser attention. As such this type of situation remained till now and the practices of waste water disposals continued and solve problems of pollution of river waters different river action plans were 
launched, but huge problem could not come under control.

\subsection{Innovative technological measures}

\subsubsection{New pattern of diverting wastewater to a pool forming wetland}

Lockdown for over three months from March to May 2020 for containing contagious pandemic COVID -19, which stopped any waste water inflow in rivers Ganga and Yamuna, led to self cleansing of bad quality water in to very clean water. This became a lesson that in the river systems no waste water, be it domestic or industrial, be dumped in rivers, irrespective of whatever quality. It means all waste water coming as sewage water should be led to any lowland in downstream direction and makes a wetland pool. How to manage the wetland was dealt with by studies (Yadav 2020a,b). The physical feature of the pattern of waste water diversion in downstream sides both left and right sides of the rivers is depicted vide Fig 2. Although wetlands must have existed in the past, but such wisdom of maintaining clean water had not existed. The innovative measure will become first insight leading to foolproof measure for cleaning of river water without undue budget and wastage of time and efforts. Such details will be taken up in result part of study.

Fig 2.

\subsubsection{Development of set up for treatment of waste water in wetlands}

A set up for storage of fresh water in the wetlands was developed in the cited study, which can be constructed at one or many locations depending on size of wetlands (Yadav, 2012, 2020). The fresh water pool facilitates living of fish under different depth of water and giving ample time for water availability in the pool for long time. As wetlands receive continuous supply of waste water the level of water in wetland is expected to remain sufficient for all time; maximum in rainy season and lowest during the summer.

Fig 3.

\subsection{Development of clean water in wetland.}

The three camber filter is depicted in Fig 3b. Its high height will enable maintain fresh water in accordance to water level in the wetland.

\subsubsection{Rearing fish in fresh water}

Rearing of fish has been highly researchable issue in regular department of Fishrry in Indian Council of Agricultural Research and State Agricultural Universities, The reared fingerlings are available at such centers. The fingerlings can be purchased and research in the fresh water in the wetlands. Such advisory services are available in the country

\subsubsection{Enhancing nutrient content of fish tankaged water for irrigation}

The waste water has been used for irrigation, which caused different problems. So far such waste waters have been finding ineffective measures, without insight of enhancing nutrient content of water that will be available. This aspect will be brought in result part of study.

\subsubsection{Harvesting of Guano from aquatic fed wild birds}

The wetlands fresh water will enable produce fish. In the system of production and consumption of such aquatic system there will be some wastage. The waste fingerlings and fish that get reared in waste water of wetlands, get eaten by the wild birds such as heron (Fig 4). The aquatic birds will produce Guano, highly rich in organic nitrogen $(\mathrm{N})$ and phosphorus $(\mathrm{P})$.

Fig 4.

\subsection{Case studies}

\subsubsection{Draining raw sewage water in a gully and causing adverse impacts}


This case study sets an example how self interest and arrogance spoils quality and quantity of ground water. India Government established a Research Centre on Soil and Water Conservation on gully erosion and reclamation in 1960s at Agra, Uttar Pradesh, at the bank of River Yamuna, ie famous City of Taj Mahal. Its research farm covered about 80 ha comprising gullied land escape. In late 1990 with expansion of population someone purchased land on the upper reach of gully, before its reach forming part in the research farm. The sewage water filled the pond and spoiled environment. With time all deep wells went dry and all experiment spoiled. Thus, non cooperation and arrogance spoiled entire research institution, who conducted research on most dense known gully erosion in the world and reclamation works. The Centre employed all about 75 research scientists, assistant workers and laborers. Thus, every effort and investment has gone to waste and groundwater became scarce and environment spoiled.

The aforementioned information will enable convince proprietary well owners and get care and blessing of general public who will safeguard against such pollution. These measures and recharge will make ground water highly productive and sustainable. The ground water governance being thrust upon in the present study takes both positive, negative and curative aspects in to consideration.

\subsubsection{Irrigation from wetland sewage water leading worsening of agriculture land}

Wetlands are now exiting even in pastoral areas, where no facilities exist for their treatments. During water scarcity the waste water available in wetlands are applied for irrigating crops. Such irrigation near famous Taj Mahal, Agra, produced devastating results on degradation of lands. This worsened situation became an example for land degradation. Such situations can be overcome by innovative technology presented in the following result part of the study.

\subsection{Processing and developing brands of products}

The guano so harvested is analyzed for its chemical constituent, separation. This product is usable for various uses, be agriculture, industrial and medical drug manufacture. Thus, waste water and land which remained un utilized for producing valuable products.

\subsection{Creating employment opportunities}

In case of large rivers banks and wet land large scale business will get organized, which enable creating regular employment of various cadres. This aspect will be again taken in research part of the study,

\subsection{Acquisition of data}

Scenarios that developed in time over three decades were synthesized for developing result part of the study.

\section{Results}

\subsection{Status of developed riparian areas}

The development of gully and ravines developed in before three decades could sustain and bringing productivity. But misdeeds developing have pulled down. Usually any such land treatment measures have useful life of 10 years and after that it needs revamping. In gully riparian areas the situation worsened land water condition. Developing population and urbanization led to dropping waste water in gully and riparian areas. The case study will substantiate this fact.

\subsubsection{Disposal of sewage water in gully}

With developments in form of urbanization, waste waters have been directly disposed off in rivers and gully, the lowest elevation in the vicinity. For reclamation of polluted water different action program have been launched, where in only sewage treatment plants have been constructed. It was observed whatever reclamation effect brought out by such measures get overshadowed by increase in waste water load, hence it were not showing noticeable impact.

The lock down during COVID 19 pandemic for over three month created self cleansing of rivers. This led to conclusion that the river systems should be made free of any dropping of waste water. For this a new 
approach was developed to divert waterwater in disposal channel and form a pool such as wetland and make the fresh water in rivers as well as gullies free from pollution. Such innovative scheme was depicted vide Fig 2. Further innovative advancement in this direction will follow.

\subsubsection{Fresh water pool in wetlands}

The previous subsection 3.2.1 established that waste water should not be disposed off in gullies which become a link in major rivers forming the riparian areas. The waste water should be conveyed to form pool and create wetland that will not pollute fresh waters in rivers. In this subsection technology was introduced to treat wetland waste water to create fresh water. Fig 3 displays new innovative design of the fresh water pool.

\subsubsection{Water filtration unit}

The new design of filter unit receives wastewater and filter by sand, followed by gravel and biochar. The biochar will absorb colors and supply fresh water. Efficiency of such filter arrangements have already been established in water supply systems. The impurities such as chlorinated chemicals are effectively removed by the biochar is revealed by the data in Table.1. Chlorinated organics which form methenogensis are adsorbed bthe biochar, hence fresh water in the sump will contain at the most nitrogen. In such waters fish will survive and prosper.

\subsubsection{Prospects of rearing fish in fresh water}

Detailed prospects of rearing fish will be possible. Fingerlings should be introduced from time to time and growing fish should be carried out. Advisory services of fishery scinitist be taken in the fresh water. Fish should be used for human, animal, rearing birds and animals as well as for making medicinal products and organic manures. The water in tank will be enriched by tankage will also get enriched by $\mathrm{N}$ and $\mathrm{P}$. This water will be salable for irrigation, without any risk of degradation of lands.

Tankage of fish rearing enhances biological nitrogen and phosphorus $\mathrm{N}$ and $\mathrm{P}$ brings new opportunity for enhancing Nutrient by tanakage. Researches (Yadav,2014, 2015 and) 2020) have established that for enhancing productivity by optimum level the recommended chemical doses of NPK, one fourth of N dose should be supplemented by organic sources(Anonymous, 2003). The enhanced level by tankage creates new opportunity for catering the organic dose by $6.5-10 \%$ and phosphorus, by $10 \%$. This positive impact shows tremendous prosperity of use of waste water, which spoil land water condition in the riparian areas. The utility of fish opens tremendous opportunity in bringing prosperity

\subsubsection{New Opportunity of harvesting guano from wastewater created wetland}

This topic of research has been getting addressed by the author and dat presented in Table 2. The new practice of harvesting aquatic feeding birds viz guano has been brought to new and current knowledge after lapse of eight decades. Fig 4. Displays scene of birds which can be harnessed by creating wild bird parks for harvesting guano.

3.2.6 Multiple uses of $\mathbf{N}$ and $\mathbf{P}$. It may be mentioned that there have been many bird sanctuaries, where wild birds come at least during winter months but no such new practice of harvesting guano existed. Thus, this study introduces new prospect of harvesting guano which will have multiple uses. Stu (Yadav, 2020) presented detailed list of multiple uses of organic $\mathrm{N}$ and $\mathrm{P}$.

\subsection{Case studies on land degradation}

\subsubsection{Land degradation due to waste water irrigation}

The purchaser established a Degree and PG college. The establishment blocked runoff water flow and drained all its sewage in the gully at its downstream, which was running through the research farm. The gully had become part of several research works such as farm pond with earthen dam, soil and water conservation structures and experimental plots of ecological studies, which produced international research articles. The research progress made installation of three deep bore wells for carrying out agricultural research studies on 
the farm. Thus such undesirable features must be happening in under the upper reach of developed riparian areas

The sewage water filled in the farm pond established in gully and spoiled all farm roads making farm road non usable. The deep tube wells dried down, making no cultivation of experimental as well as other part of farm land. Thus, entire asset created in almost four decades got vanished and national prestigious facility reached to condition of abandoning. The water qualities of the riparian areas were already spoiled, for which alternative innovative measure as displayed in Fig 2 was innovated.

\subsubsection{Devastations by irrigation using waste water}

As brought out irrigation at downstream of River Taj Mahal, a famous archeological monument at the right bank of the river Yamuna, at Dhandhupur spoiled all good quality arable land. It became an exemplary case for citing devastations of land irrigated by wastewater. As such there existed no simple measure to overcome widely spreading development of land degradation.

The case as displayed by Fig 3, the waste water in the wetland get cleared and treated in to fresh water also eliminated of all impurities and also its water quality enhanced by tankage will become good source of irrigation water. Thus, innovative technology improves water quality and salable for needy for irrigation. This innovation will save such degradation of riparian areas. The waste water which caused devastation was brought to enhanced biological $\mathrm{N}$ and $\mathrm{P}$, that will cater need of vast areas in any area and place. This product became marketable product for economic growth.

\subsubsection{New prospecting technology module for overcoming degradation of riparian areas}

The two cases cites in section 3.4.1 1nd 3.4.2 established occurrence of situation not foreseen about three decades and before, which made it vast land degradation now. In order to overcome such situation a new technological synthesized module is that stop drainage of wastewater in gully, divert it to form a wetland pool and treat wastewater and build setup for storage of such fresh water, enhance its productivity by rearing fish, non dispensable user of water, enhance nutritional quality of fresh water by tankage of fish rearing, which will become good quality irrigation water. The development of fish fingerlings should be useable by the wild birds such as heron (Fig 5) which will produce dropping viz guano, rich source for biological N and P. This technology will eliminate devastation factor in to highly beneficial resource and product of esteem values needed for contemporary economic growth of nation (Raj et al 2011). This innovative technology module adoption brings natural action and makes it toil free management of aquatic ecosystem. The ground water development will enable use of land and several water conservation technologies will find place in creating sustainable use of riparian areas.

\subsection{Linking of aquatic ecosystem, birds and agriculture in self supplementing revolving nature based system}

The innovations presented here enable linking aquatic system, specially of waste water in productive capacity, non dispensable use of water, wild bird rearing and harvesting biological $\mathrm{N}$ and $\mathrm{P}$ highly useful in agriculture as a natural food chain developing as a natural process. The contributing factor had been working in isolations and creating devastations as cited by the case studies and brought in self operating toil free ecosystem services. This innovative development will serve cause of present and posterity and enhance sustainability of riparian areas. The technologies presented here pave ways for establishing domestic birds such as poultry and duckery and wild bird rearing farm for biological harvesting of guano which becomes nearly non dispensable user of water. Thus, wastewater which spoiled desirable feature of land and water will get restored by adoption of this technology module, which is depicted by Fig 5. This research sets policy tool for keeping riparian areas make sustainable by theory and its moderate change in accordance to customized research. Thus, this study makes a global thinking and local action for accomplishment of contemporary economic growth.

Fig 5. 


\subsection{Creating employment opportunities for local people and overcoming devastating situation as of COVID 19}

India launched Mahatma Gandhi National Rural Employment Guarantee Act (MGNREGA), where most of work involves deepening or desilting of ponds in the area, in addition of making rural soil roads etc. This employment guarantee act provides 100 days employment of earth work, irrespective of nay qualification, which creates hardship for the wage earners.

This research creates such employment and goes in building regular employment of different caders for educated professionals. The study generates organization of business which produces resources and marketable products. Such developments had been created for wet land. In the present study it starts creating wastelands and builds several reources and products.

\section{Discussions}

This research has brought out developing situations on riparian areas, what had been adverse impacts of misdeeds, innovative technologies that eliminate such limitations established by case studies. This following discussion is set to ratify the results and their wider application under different sub heads.

\subsection{Sustainability of developments of gully susceptible riparian areas}

Gully eroded land with severe situation falling all along river systems in India were brought up about three decades ago, which produced enhanced yields and contributed country's production. Usually the expected useful life of land developments is taken up for 10 years. Thus, by now the development of land has already passed successful life. Therefore, it needs revamping of riparian areas for restoration of productivity. The main widely spread drawback is lack of plant nutrient in the form of macro and micro nutrients.

Post developments inducement of prosperity that brought urbanization and development of urban facility in rural areas, which followed disposal of untreated waste waters in gullies that ultimately joined major river systems causing pollution of river water. Further, climate change adversely suppressed ground water level, making the riparian areas water wells getting dried. Thus, the productivity of systems have again been declining.

\subsection{Stopping direct sewage disposal and diverting it to form a wetland pool}

The long time lock down during COVID 2019 led to self cleansing of river waters, this gave a lesson that diversion of wastewater in downstream to make and wetland is the only way to overcome problem of water pollution in the riparian areas. There had been lack of appropriate technology for treatment of wastewater in the wetland. The example of fires inPerimbdoor lake in Bangalore, Karnataka State of India, showed that there is lack of effective technology for treatment of wastewater.

\subsection{New innovative technology module for creating fresh water and its storage in lakes}

A new technological synthesized module is that stop drainage of wastewater in gully, divert it to form a wetland pool and treat wastewater and build setup for storage of such fresh water, enhance its productivity by rearing fish, non dispensable user of water, enhance nutritional quality of fresh water by tankage of fish rearing, which will become good quality irrigation water. The development of fish fingerlings should be useable by the wild birds such as heron which will produce dropping viz guano, rich source of biological $\mathrm{N}$ and $\mathrm{P}$. This technology will eliminate devastation factors in to highly beneficial resource and product of esteem values needed for contemporary economic growth of nation (Raj et al 2007). The ground water development will enable use of land and several water conservation technologies will find place in creating sustainable use of riparian areas.

\subsection{Sufficiency of research accomplishments}

The technologies presented have solid foundation and sufficiency of other aspects. Thus, diversion of waste water is proven fact. Innovative technology of wastewater treatment, its use by fishery, rearing wild birds and harnessing biological $\mathrm{N}$ and $\mathrm{P}$ are from long time 9 For over eight decades. Thus, entire aspects have been 
sufficiently established. Therefore, innovative technologies are having sufficiently research base are highly applicable, beyond any doubt.

\section{Conclusion}

This research established status of riparian areas development about three decades The riparian rivers suffered pollution by sewage disposal following development prosperity and urbanization. This study resented curative and alternative strong measures to make best use of diverted waste water and produce upon dispensable use of water and building biological nitrogen $(\mathrm{N})$ and phosphorus $(\mathrm{P})$ and their multiple product processing and branding. The innovative measure will produce prosperity and employment. The measures application will improve productivity of riparian areas and go long way in inducing sustainability.

\section{Acknowledgements}

Author duly acknowledges references cited in support of statements made in preparation of the manuscript.

\section{Declaration of no conflict of any interest, be financial or authorship}

No funding was received from any sources viz Governmental or non Governmental and Social Organization. It is further declared that there exists no any clash of interest, be it financial or for authorship.

\section{References}

Anonymous,(2003). Rehabilitation of gullied and ravine lands. Deparment of Land resources, Ministry of Rural Development Govt of India.Technical Brochure.DOLR/MORD.01/2003.pp 1-44.

Bhushan L.S, Yadav, R.C and Gurmel Singh, (1991). Augmentation of vertical growth of agriculture by land abd water management.. J agri Sci. 61(7):459-64.

Bhushan, L.S, Yadav, R.C, Singh B.L. Tiwari A.K. Singh, M, Gaur ,M.L and Babu Ram.(1992).Prospects for rainfed agriculture in gullied and ravine catchments through soil and water conservation practices.. J Arid Environmant.23:433-441.

Bhushan, I.S, Sharma, A.K., Tiwari, A.K, Singh, B.L and Yadav, R.C. (1997).Management of ravine watershed (Evaluation results and Directions): Sheetal pur, Hamir pur-Bundelkhand region.Bulletin No:T-37/A-1: $1-47$.

Guftafson, A. E. (1939/2010). Hand Book of fertilizers, make, effects and use.. Third Edition Agro Bios .Jodhpur India.pp 15.

Raj Fellix, Mukharji, Sampat, Mukherji Millinath, Ghosh, Amitav and Nag Rajendran.(2007). Contemporary development economics from Adam Smith to Amaratya Sen. New Central Book Agency Pvt Ltd. London, Delhi, Kolkata,, Hyderabad pp323 - 63.

Warren, S. Thompson and Baver, T. Levis. (1965). Population problem. 5th Edition. New York, 726 Mc Graw Hill, P 304.727.

Yadav, RC.(2012). Innovative application of scientific facts for nutrient recovery from waste water streams for sustainable agriculture and protection of environment.:A Review".Hydrology Current Research, USA $.3: 1-11$.

Yadav, R.C. (2014). Biological nitrogen harvesting from aquatic eco systems-A new scientific vision. Fish and Aqua Culture Journal. U.S.A. 15(3):

Yadav, R.C. (2015). Biological phosphorus harvesting for multiple uses- A new scientific vision. J Aqua Culture and Marine Biology. S.A. 2(2):

Yadav, R.C.(2020).Wetlands' generated natural assets through fishery and aquatic birds' boosting prosperity and employment. Med Crave J Aquculture and Marine Biology.U.S.A. Under Review 
Yadav R. C. and Bhushan, L.S. (2002) Conservation of gully susceptible riparian areas in the deep alluvial soil region. Land Degradation and Development. U.K. 13: 201-219.

Yadav, R.C.,Bhushan, L.S and Raghuvir,(1989). Specifications for terracing of gully and ravine lands for agriculture.. J soil and Water Conserv in India.33:39-48.

\section{Hosted file}

INNGULRIPFIG-converted.pdf available at https://authorea.com/users/335867/articles/461650innovative-technological-restoration-of-gully-susceptible-riparian-land-and-watersustainable-productivity

\section{Hosted file}

INNGULTXTUNANY.docx available at https://authorea.com/users/335867/articles/461650innovative-technological-restoration-of-gully-susceptible-riparian-land-and-watersustainable-productivity

\section{Hosted file}

INNGULTABLE. docx available at https://authorea.com/users/335867/articles/461650-innovativetechnological-restoration-of-gully-susceptible-riparian-land-and-water-sustainableproductivity

\section{Hosted file}

MAINTEXTFILEGULLY.docx available at https://authorea.com/users/335867/articles/461650innovative-technological-restoration-of-gully-susceptible-riparian-land-and-watersustainable-productivity 
Innovative technological restoration of gully susceptible riparian land and water sustainable productivity
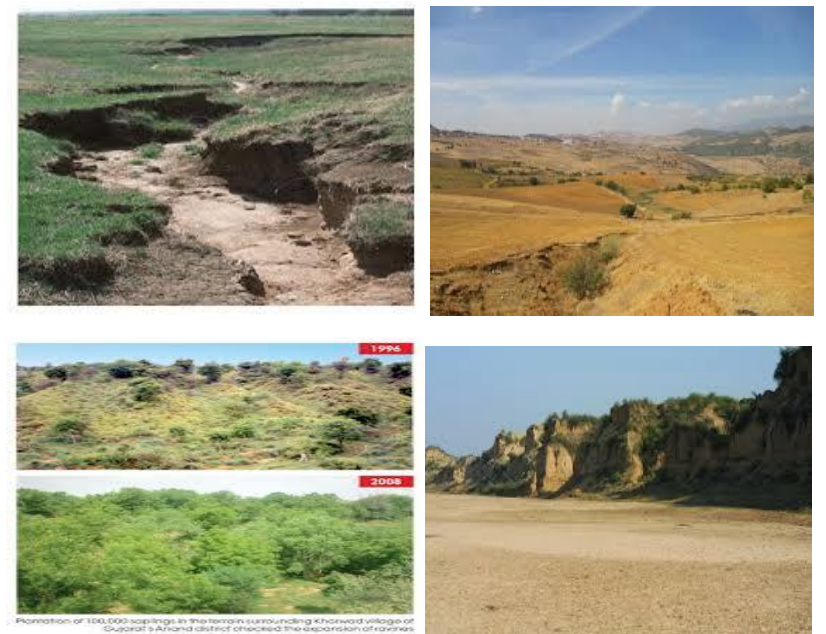

5

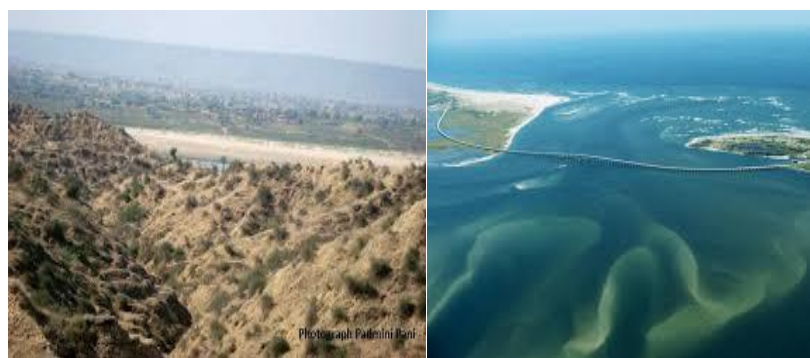

7 Fig1. 